\title{
Influence of whey protein hydrolysis in combination with dextran glycation on immunoglobulin E binding capacity with blood sera obtained from patients with a cow milk protein allergy
}

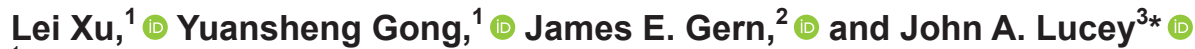 \\ ${ }^{1}$ Department of Food Science, University of Wisconsin-Madison, 53706 \\ ${ }^{2}$ School of Medicine and Public Health, University of Wisconsin-Madison, 53706 \\ ${ }^{3}$ Center for Dairy Research, University of Wisconsin-Madison, 53706
}

\begin{abstract}
Food protein allergies are a major global concern. Hydrolysis of food proteins reduces their allergenicity, but another novel approach is the covalent attachment of polysaccharides to proteins via the Maillard reaction (i.e., glycation), which blocks some $\operatorname{IgE}$ binding epitopes on the protein allergen. We wanted to examine whether enzymatic hydrolysis, combined with glycation, could further reduce IgE binding for people with a cow milk protein allergy. Whey protein isolate (WPI) was hydrolyzed by immobilized trypsin and chymotrypsin to degree of hydrolysis (DH) values of 17 to $27 \%$. Immobilized enzymes were used to avoid heat-treating the hydrolysate (to inactivate the enzymes, because heating could also affect the IgE binding ability of the protein). The resultant whey protein isolate hydrolysates (WPIH) were then glycated with $10-\mathrm{kDa}$ dextran (DX) in aqueous solutions held at $62^{\circ} \mathrm{C}$ for $24 \mathrm{~h}$. We analyzed the molar mass $\left(M_{W}\right)$ of WPIH samples and their corresponding glycates (WPIH-DX) using sizeexclusion chromatography with multi-angle laser light scattering. We obtained blood sera from 8 patients who had been diagnosed with a cow milk protein allergy, and we used a composite serum for IgE binding analysis. The average $M_{W}$ values of samples WPIH-1 to WPIH-3 decreased from $11.15,9.46$, and $7.57 \mathrm{kDa}$ with increasing DH values of $18.7,22.5$, and $27.1 \%$. Glycation significantly reduced the high bitterness of the WPIH samples, as assessed by a trained sensory panel. The WPIH-DX glycates had significantly reduced WPI-specific IgE binding capacity compared to WPI or unglycated WPIH; we found an almost 99\% reduction in IgE binding for the WPIH-DX glycate made from WPIH with a DH value of $27.1 \%$. Hydrolysis of WPI
\end{abstract}

Received June 28, 2019.

Accepted October 4, 2019.

*Corresponding author: jlucey@cdr.wisc.edu followed by glycation with DX via the Maillard reaction significantly decreased the allergenicity of whey proteins.

Key words: whey protein isolate, dextran, hydrolysis, allergenicity, cow milk protein allergy

\section{INTRODUCTION}

An increasing number of people have food protein allergies, and this has become a growing concern around the world (Ballmer-Weber, 2011). Cow milk protein allergies (CMPA) are among the most common food allergies in children, with a prevalence ranging from 2 to 7\% (Wal, 1998; Høst, 2002). The CMPA reaction is immunologically mediated, by both $\operatorname{IgE}$ and non-IgE, and is triggered by several potential antigens in cow milk (Wal, 1998; Calabria et al., 2009). Whey protein, a major protein ingredient in infant formula, is a key target for reducing the allergenicity of milk products intended for people with a CMPA (mostly children).

Processing methods that are used to try to reduce the allergenicity of cow milk proteins include heat treatment, enzymatic hydrolysis, and fermentation (Wal, 2002). Milk protein hydrolysis has been shown to enhance immunity and decrease IgE levels in ICR mice (Pan et al., 2013). When human milk is not available for preterm infants, protein hydrolysates are often used instead of standard cow milk formulas (Dupont and De Boissieu, 2003). However, it is not clear if protein hydrolysates significantly improve feed intolerance $(\mathrm{Ng}$ et al., 2017). During protein hydrolysis, the potential allergenic epitopes, mainly linear epitopes, may be altered or cleaved (Wroblewska et al., 2004; Hays and Wood, 2005), causing a reduction in IgE binding. The degree of hydrolysis (DH) and the types of enzyme used are some of the most important factors influencing the effectiveness of protein hydrolysis in reducing IgE binding (Svenning et al., 2000; Giampietro et al., 2001; Hays and Wood, 2005; Reche et al., 2010). The molar mass $\left(\boldsymbol{M}_{\boldsymbol{W}}\right)$ of the peptides in the hydrolyzed 
protein are an important parameter in determining allergenicity (Van Hoeyveld et al., 1998; Puerta et al., 2006). However, extensive protein hydrolysis can result in bitterness and poor functional properties (Nnanna and $\mathrm{Wu}, 2007$ ).

Glycation (also called conjugation) of milk proteins with polysaccharides via the Maillard reaction is an effective way to improve functionality (see reviews by de Oliveira et al., 2016; O'Mahony et al., 2017). Milk proteins have been glycated with polysaccharides of different $M_{W}$ under various conditions to try to reduce allergenicity (e.g., Kobayashi et al., 2001; Hattori et al., 2004; Xu et al., 2018). A novel aqueous method for the glycation of whey proteins using macromolecular crowding was developed by Zhu et al. (2008). Previous work (Xu et al., 2018) by our group indicated that glycation of whey protein isolate (WPI) with dextran (DX) of different $M_{W}$ (as determined by size-exclusion chromatography coupled with multiangle laser light scattering; SEC-MALLS) significantly decreased IgE binding. Glycation created steric hindrance on the surface of the protein because of the attachment of DX molecules (Xu et al., 2018). However, a reduction of only about $20 \%$ in IgE binding was reported as a result of the glycation of WPI with DX (Xu et al., 2018).

The objective of this study was to combine 2 techniques (protein hydrolysis and glycation) that each partially reduce $\operatorname{IgE}$ binding, and to determine whether a combination of these 2 methods would more effectively reduce $\operatorname{IgE}$ binding. It has been reported that protein hydrolysates with improved solubility can be prepared by glycation with sugars or polysaccharides via the Maillard reaction (Mulcahy et al., 2016). In this study, we evaluated a combination of whey protein isolate hydrolysates (WPIH) and WPIH glycated with DX (WPIH-DX) to further decrease the $\operatorname{IgE}$ binding capacity of whey proteins. We also compared these to simple mixtures of WPI+DX or WPIH+DX (i.e., not glycated, just mixed together). In $\mathrm{Xu}$ et al. (2018), the IgE binding capacity was evaluated using the ImmunoCAP test, one of the standard tools for in vitro allergy diagnosis in US hospitals (Johansson, 2004). We hypothesized that glycation of WPIH with DX could shield the remaining epitopes of whey proteins, limiting the accessibility of $\mathrm{IgE}$ binding and further reducing the IgE binding capacity of WPIH. The WPI was hydrolyzed into peptides with different DH values using trypsin and chymotrypsin, followed by glycation with DX with a $M_{W}$ of $10 \mathrm{kDa}$ using the wet (aqueous) process developed by Zhu et al. (2008). The enzymes for hydrolysis were covalently immobilized on activated agarose gel to avoid severe heat treatment for enzyme inactivation, and to avoid the complicating effect of residual enzymes on the IgE binding capacity test. Severe heat treatment could also affect the $\operatorname{IgE}$ binding capacity of whey proteins. We evaluated the DH of WPI by checking the average $M_{W}$ and accessible $\mathrm{NH}_{2}$ groups. After characterizing the corresponding glycates, we tested the WPI-specific IgE binding capacity compared with unglycated proteins or peptides. This was the first study to use a combination of enzymatic hydrolysis and glycation approaches to reduce the $\operatorname{IgE}$ binding capacity of WPI. We evaluated the IgE binding capacity of glycates using sera obtained from patients with a CMPA.

\section{MATERIALS AND METHODS}

\section{Materials}

Whey protein isolate was obtained from Davisco Foods International Inc. (Le Sueur, MN) that had a total protein content of $>95 \%$ (dry basis) and a lactose content of $<1 \%$. The WPI was thoroughly dialyzed against Milli-Q water (Millipore Corp., Billerica, CA) for $3 \mathrm{~d}$ at $5^{\circ} \mathrm{C}$, and the water was changed every $6 \mathrm{~h}$ to remove residual lactose and minerals (Xu et al., 2018). The dialysis membrane tubing had a $M_{W}$ cutoff of 6,000 to 8,000 Da (Spectrum Laboratories, Inc., Rancho Dominguez, CA). After lyophilization, the purified WPI powders were stored at $5^{\circ} \mathrm{C}$. We obtained DX from Leuconostoc mesenteroides, with a reported $M_{W}$ of $10 \mathrm{kDa}$, from Pharmacosmos (Holbaek, Denmark). Before use, the DX was dialyzed for $2 \mathrm{~d}$ against Milli-Q water using a dialysis membrane with a $M_{W}$ cutoff of 6,000 to 8,000 Da to remove low $M_{W}$ oligosaccharides (Xu et al., 2018). We obtained Sepharose 6B gels from Pharmacia Fine Chemicals (Uppsala, Sweden). We purchased bovine pancreas trypsin and bovine pancreas $\alpha$-chymotrypsin from Sigma-Aldrich (St. Louis, MO). Blood sera from 8 patients who were clinically diagnosed with a CMPA were provided by the University of Wisconsin-Madison Department of Medicine, Division of Allergy and Clinical Immunology. The sera were obtained from children who participated in the Childhood Origins of Asthma Study and had IgE binding capacity to milk proteins of $>0.5 \mathrm{kUA} / \mathrm{L}$. We received institutional board review approval to use these sera.

\section{Preparation of Trypsin-Agarose and Chymotrypsin- Agarose Derivatives}

The enzymes were covalently immobilized on activated agarose gel to avoid the need for enzyme deactivation by heat treatment (Nnanna and Wu, 2007), which could have caused protein aggregation and affected the 
glycation reaction, as well as the $\mathrm{IgE}$ binding capacity test.

Activation of the agarose gel (Sepharose 6 B) was based on the method developed by Shainoff (1980). Glyoxyl-agarose gel ( $\left.\mathrm{Ag}-\mathrm{O}-\mathrm{CH}_{2}-\mathrm{CHO}\right)$ was prepared by reacting cross-linked $6 \%$ (wt/wt) agarose gel with glycidol (2, 3-epoxypropanol), and the resultant glycerylagarose gel $\left(\mathrm{Ag}-\mathrm{O}-\mathrm{CH}_{2}-\mathrm{CHOH}-\mathrm{CH}_{2} \mathrm{OH}\right)$ was further oxidized with periodate. Then, $20 \mathrm{~mL}$ of packed $6 \%$ agarose gel (Sepharose 6B) was washed with water and mixed with $2 \mathrm{~mL}$ of glycidol (Sigma-Aldrich), and 10 $\mathrm{mL}$ of $1 M \mathrm{NaOH}$ containing $\mathrm{NaBH}_{4}(2 \mathrm{mg} / \mathrm{mL})$ as an antioxidant. The mixture was stirred for about $18 \mathrm{~h}$ (overnight) at an ambient $25^{\circ} \mathrm{C}$, and then washed with water 3 times to decrease the $\mathrm{pH}$ to 7 to 8 . The resultant glyceryl-agarose was suspended in water to total volume of $40 \mathrm{~mL}$, then admixed with $7 \mathrm{~mL}$ of $0.16 M$ $\mathrm{NaIO}_{4}$, and stirred for an hour. The slurry was washed with Milli-Q water and suspended to $0.1 \mathrm{M}$ borate buffer, $\mathrm{pH}$ 10, before mixing with enzymes (Guisán et al., 1991).

Trypsin and chymotrypsin, each $40 \mathrm{mg}$, were mixed with $40 \mathrm{~mL}$ of an aqueous suspension of activated $6 \%$ agarose containing $20 \mathrm{~mL}$ of packed gel ( $\mathrm{pH} 10)$. The mixture was gently stirred at $25^{\circ} \mathrm{C}$ for $1 \mathrm{~h}$. The activated gel was completely reduced with $80 \mathrm{mg}$ of solid sodium borohydride (to reduce free aldehyde groups and residual $\mathrm{NaIO}_{4}$ ) at $25^{\circ} \mathrm{C}$ for $30 \mathrm{~min}$. The activated gel (containing immobilized enzymes) was washed by $0.1 M$ phosphate buffer $(\mathrm{pH} 7) 3$ times before storage at $4^{\circ} \mathrm{C}$.

\section{Preparation of WPIH}

The WPIH were prepared based on the method described by Custodio et al. (2005). First, $2 \mathrm{~g}$ of WPI dissolved in $50 \mathrm{~mL}(40 \mathrm{mg} / \mathrm{mL})$ of water was incubated with $20 \mathrm{~mL}$ of immobilized enzyme-agarose gel at $50^{\circ} \mathrm{C}$ (pH 9) for 60, 120, and 240 min to generate samples WPIH-1, WPIH-2, and WPIH-3, respectively. We determined the $\mathrm{DH}$ values for the hydrolysates using the $o$-phthalaldehyde method described by Nielsen et al. (2001). After centrifugation at 3,000 $\times g$ for $20 \mathrm{~min}$, the supernatant $(\mathrm{WPIH})$ was lyophilized and stored at $5^{\circ} \mathrm{C}$.

\section{Preparation of WPI-DX and WPIH-DX Glycates}

The glycation protocol was based on the methods described by Zhu et al. (2008) and Xu et al. (2018). The WPI or WPIH (10\%, wt/wt) were mixed with DX (30\%, wt/wt) and rehydrated in $10 \mathrm{~m} M$ sodium phosphate buffer ( $\mathrm{pH} 6.5)$, and the mixtures were stirred overnight at $5^{\circ} \mathrm{C}$. Following $\mathrm{pH}$ adjustment to 6.5, samples were incubated in a water bath at $62^{\circ} \mathrm{C}$ for 24 $\mathrm{h}$. The concentration of DX in all cases was high, such that macromolecular crowding inhibited the denaturation and aggregation of whey proteins during incubation (Zhu et al., 2008). The glycation process was monitored based on Schiff base formation (Zhu et al., 2008), and advanced color development was monitored by measuring difference UV (DUV) absorbance at 420 nm (Jiménez-Castaño et al., 2007). The reaction was stopped by cooling the solution in ice water. The solutions were centrifuged at $3,000 \times g$ for $20 \mathrm{~min}$ to remove insoluble DX and proteins. The supernatants (WPI-DX and WPIH-DX glycates) were lyophilized and stored at $5^{\circ} \mathrm{C}$. The WPI-DX production was described recently by Xu et al. (2018).

\section{SDS-PAGE}

We performed SDS-PAGE on native WPI, WPIH, WPI-DX, and WPIH-DX glycates to determine the extent of glycation (Zhu et al., 2008; Xu et al., 2018). We carried out the SDS-PAGE analyses using a MiniProtean 3 cell from Bio-Rad Laboratories (Hercules, CA) based on the method of Laemmli (1970). The samples were diluted with Laemmli sample buffer (1:2) and loaded onto 10-well Mini-Protean TGX Precast Gels (Tris-HCl, 4-20\%; Bio-Rad Laboratories). The loading concentration of each sample was $5 \mathrm{mg} / \mathrm{mL}$ (on a protein basis), and loading volume was $20 \mu \mathrm{L}$. Gels were run for 35 min at $200 \mathrm{~V}$ in a $25 M$ Tris- $\mathrm{HCl}$ buffer (pH 8.3, including $0.192 M$ glycine and $0.1 \%$ wt/wt SDS) at room temperature. Afterward, gels were stained for protein with Coomassie Brilliant Blue G-250 (Bio-Rad Laboratories), or for glycoproteins using a GelCode glycoprotein staining kit (Pierce Biotechnology, Rockford, IL). The gel was destained with $10 \%$ acetic acid (vol/ vol) and washed with Milli-Q water.

\section{SEC-MALLS}

We performed SEC-MALLS according to the methods of Wang and Lucey (2003) and Xu et al. (2018). Lyophilized WPI, WPIH, DX, and glycates were reconstituted in $20 \mathrm{~m} M$ imidazole and $50 \mathrm{~m} M \mathrm{NaCl}$ buffer (pH 7), and left overnight at $5^{\circ} \mathrm{C}$ for hydration. Sample concentrations were selected as $0.2 \%$ (wt/wt) for WPI and WPIH, $1 \%$ (wt/wt) for DX, and $0.4 \%$ (wt/wt) for glycates to give high but not oversaturated refractive index (RI) signals. Before loading, samples were ultracentrifuged for $90 \mathrm{~min}$ at $52,000 \times g$ and filtered through a $0.22-\mu \mathrm{m}$ filter to remove large particles. Then, $50 \mu \mathrm{L}$ of each sample was loaded onto the SEC system at a flow rate of $0.5 \mathrm{~mL} / \mathrm{min}$. The SEC system consisted of 
a Waters 600 HPLC unit (Waters Corp., Milford, MA) connected to a SEC Superose 6HR 10/30 and a SEC Superose 12HR 10/30 column (Amersham Pharmacia Biotech AB, Uppsala, Sweden). The SEC columns were maintained at approximately $40^{\circ} \mathrm{C}$ throughout the experiments. We used 3 detectors for data collection: a UV detector operating at $280 \mathrm{~nm}$ (Waters Corp.; model 996); a DAWN-EOS MALLS photometer system (Wyatt Technology, Santa Barbara, CA) fitted with a helium neon laser $(\lambda=690 \mathrm{~nm})$ and a K-5 flow cell; and a differential RI detector (Waters Corp.; model 2410). We calculated $M_{W}$ distributions using ASTRA software (version 4.73.04; Wyatt Technology), using the Debye fit method (Xu et al., 2018). The dn/dc (RI increment) values used were $0.185 \mathrm{~mL} / \mathrm{g}$ for WPI and WPIH, 0.140 $\mathrm{mL} / \mathrm{g}$ for DX, and $0.160 \mathrm{~mL} / \mathrm{g}$ for glycates, respectively (Lucey et al., 2000; Jung et al., 2006).

\section{Compositional Analysis of Glycates}

The bicinchoninic acid (BCA) assay was used to estimate protein concentrations. The WPI, WPIH, $\mathrm{WPI}+\mathrm{DX}$ mixture, WPIH+DX mixtures, and WPIDX and WPIH-DX glycates were dissolved in $10 \mathrm{mM}$ sodium phosphate buffer. We assayed the protein concentrations of the solutions using a bicinchoninic acid assay kit (Pierce Biotechnology, Rockford, IL). We calculated the protein concentrations using a WPI standard curve. Carbohydrate content was estimated as the difference remaining in the solids after protein analysis. We measured the molar concentration of accessible $\mathrm{NH}_{2}$ groups in the glycates according to Nielsen et al. (2001) and Church et al. (1983). Lyophilized WPI, WPIH, and glycates were reconstituted in Milli-Q water to a final protein concentration of $1 \mathrm{mg} / \mathrm{mL}$ (Xu et al., 2018). Then, $400 \mu \mathrm{L}$ of each sample were mixed with $3 \mathrm{~mL}$ of an o-phthalaldehyde solution containing $0.8 \mathrm{mg} / \mathrm{mL}$ $o$-phthalaldehyde, $1 \mathrm{mg} / \mathrm{mL}$ SDS, and $0.88 \mathrm{mg} / \mathrm{mL}$ dithiothreitol. After 2 min, we measured the optical density at $340 \mathrm{~nm}$. We then calculated the concentration of free $\mathrm{NH}_{2}$ groups $(\mathrm{nmol} / \mathrm{L})$ using a serine standard curve. We used degree of glycation (DG) to evaluate the glycation degree of DX with WPI/WPIH. We defined DG values as the decrease of the accessible $\mathrm{NH}_{2}$ groups as a percentage of the accessible $\mathrm{NH}_{2}$ groups of unglycated WPI/WPIH.

\section{Sensory Evaluation of Bitterness}

Five samples (WPI, 2 WPIH, and 2 WPIH-DX glycates) were evaluated by 10 trained panelists in duplicate; each sample was brought to room temperature before evaluation. Solutions containing 5\% (wt/ wt) protein were used for sensory testing. Descriptive evaluation of bitterness was performed using the Spectrum method on a 15-point scale (Dus et al., 2018). All panelists had at least $40 \mathrm{~h}$ of training. The following references were used for the bitterness scale: scores of 0 , $1.5,4.0,7.5,9.25$, and 11.0 were created using distilled water, and caffeine solutions containing 0.015, 0.030, $0.050,0.075$, and $1.0 \%$ (wt/wt) caffeine, respectively. Data analysis was performed using RedJade (Tragon Corporation, Redwood Shores, CA) using $\alpha=0.05$.

\section{IgE Binding Capacity of WPI-DX Glycates}

Based on the method of Sampson (2001), $200 \mu \mathrm{L}$ of blood sera and $20 \mu \mathrm{L}$ of WPI, WPIH, WPI+DX, $\mathrm{WPIH}^{+} \mathrm{DX}$, or glycates were mixed to $100 \mu \mathrm{g} / \mathrm{mL}$ (on a protein basis). No purification was used for the WPIH or WPIH-DX samples. Samples were incubated at $5^{\circ} \mathrm{C}$ overnight and loaded onto an ImmunoCAP 100 system (Phadia, Uppsala, Sweden). Whey protein isolate caps were used as a stationary phase (ImmunoCAP allergen Rf236; Phadia). We also performed control experiments with $10 \mathrm{~m} M$ sodium phosphate buffer and DX. The IgE levels measured after pre-incubation with a sodium phosphate buffer control $(0 \mu \mathrm{g} / \mathrm{mL}$ protein $)$ were regarded as the maximum WPI-specific IgE response $(100 \%)$. All other results were expressed as a percentage of that response.

\section{RESULTS AND DISCUSSION}

\section{Preparation and Properties of WPI-DX and WPIH-DX Glycates}

The WPI was hydrolyzed to WPIH with different DH values by controlling the hydrolysis time for samples held at $50^{\circ} \mathrm{C}$ and $\mathrm{pH} 9$ (Figure 1). The WPIH-1, WPIH2 , and WPIH-3 samples had DH values of 18.7, 22.5, and $27.1 \%$, respectively. We observed a decrease in the average $M_{W}$ (as measured by SEC-MALLS) with increasing DH. The WPIH-1, WPIH-2, and WPIH-3 samples had average $M_{W}$ values of $11.15,9.46$, and 7.57 $\mathrm{kDa}$, respectively.

The WPI and WPIH were glycated with DX of $M_{W}$ $10 \mathrm{kDa}$ by the Maillard reaction, and the reaction was stopped at the first stage (mostly) to stop the Maillard reaction from progressing to the more advanced stage (i.e., forming brown colors, known as melanoidins; de Oliveira et al., 2016). During incubation, we monitored DUV values, which are related to the formation of Schiff base (Figure 2). The levels of glycated material gradually increased with time during incubation, following a pseudo-first-order reaction, consistent with previous 


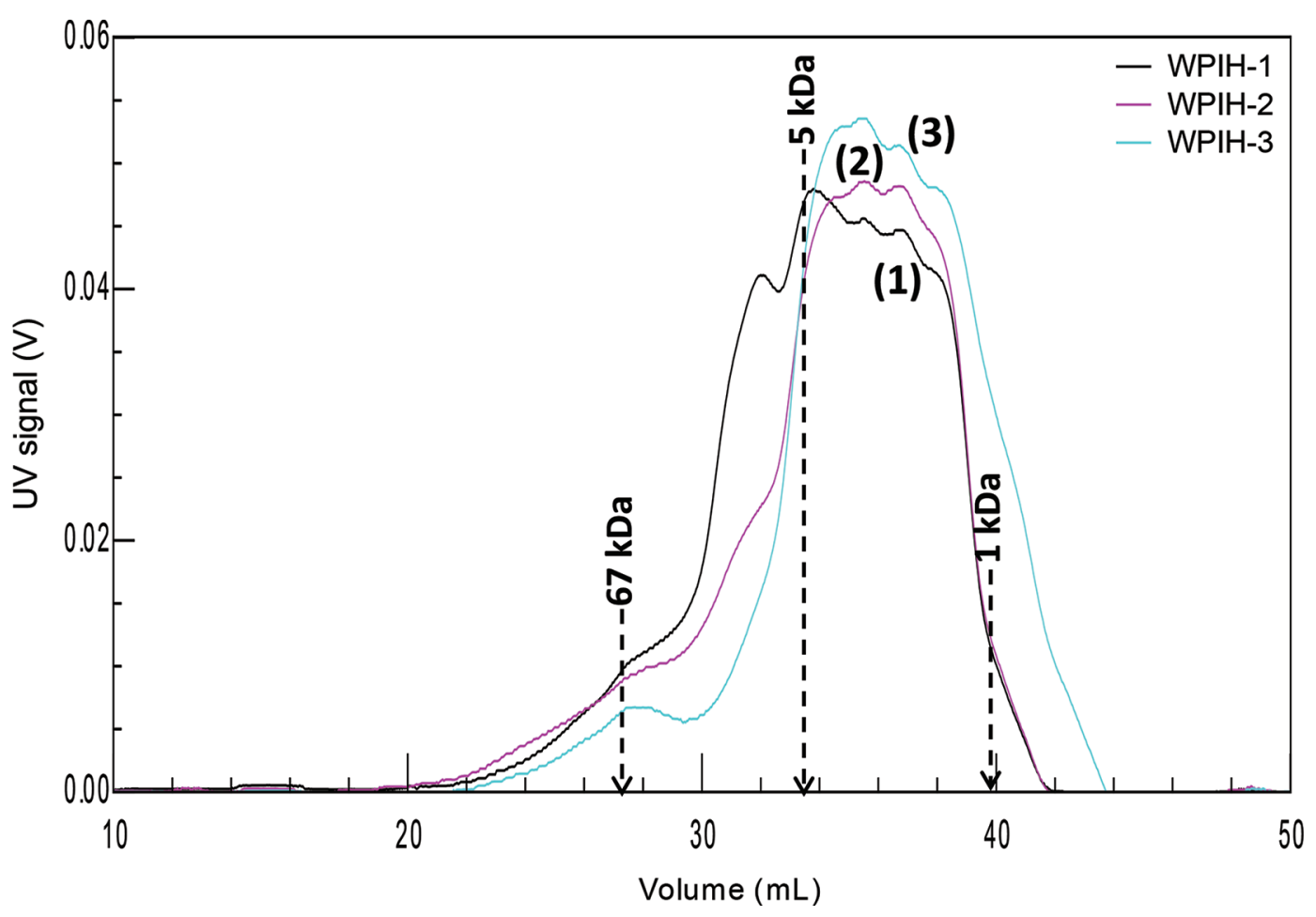

Figure 1. Size-exclusion chromatography coupled with multiangle laser light scattering (SEC-MALLS) elution profiles of whey protein isolate hydrolysates (WPIH) hydrolyzed at $50^{\circ} \mathrm{C}$ for $60 \mathrm{~min}$ (WPIH-1), $120 \mathrm{~min}$ (WPIH-2), and $240 \mathrm{~min}$ (WPIH-3). The UV signals of WPIH-1 (1, black), WPIH-2 (2, pink), and WPIH-3 (3, blue).

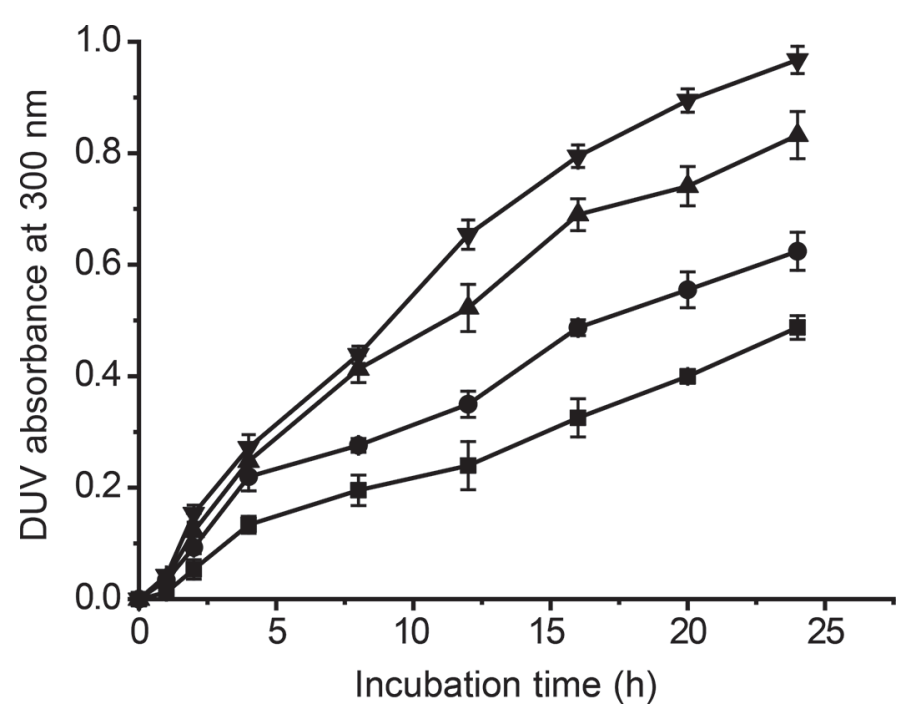

Figure 2. Effect of heating temperature and time on Schiff base formation in whey protein isolate glycates with dextran (WPI-DX) and whey protein isolate hydrolysate glycates with dextran (WPIHDX) as indicated by the difference UV (DUV) peak at $300 \mathrm{~nm}$ : WPI

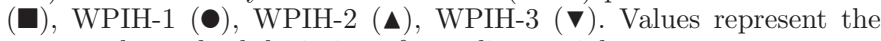
mean and standard deviation of 3 replicate trials. results (Allelein et al., 2012). We observed a steeper DUV versus time slope in WPIH samples: the highest DH $(27.1 \%)$ indicated a faster glycation reaction in highly hydrolyzed samples. We monitored DUV values at $420 \mathrm{~nm}$ during incubation to investigate this color development, which we used as an index of advancedstage Maillard reaction products (results not shown).

The SDS-PAGE electrophoretograms of glycates stained with a protein stain (Coomassie blue) and carbohydrate stain (periodic acid stain) confirmed the formation of a stable covalently bound glycates (Figure 3). Bands with $M_{W}$ of 14,18 , and $66 \mathrm{kDa}$ in WPI (lane 1; Figure 3a) corresponded to $\alpha$-LA, $\beta-\mathrm{LG}$, and BSA, respectively. Some unreacted $\beta$-LG remained in the WPI-DX sample, as previously reported (Xu et al., 2018). In the WPIH samples (lanes 2, 3, and 4; Figure 3a), the intensity of bands corresponding to $\alpha$-LA and $\beta$-LG decreased; the simultaneous formation of smeared bands (various $M_{W}$ size distribution) at a lower $M_{W}$ range indicated the hydrolysis of $\alpha-\mathrm{LA}$ and $\beta-\mathrm{LG}$ into small peptides. For WPIH-3 (lane 4; Figure $3 a)$, which had a $\mathrm{DH}$ value of $27.1 \%$, the majority of $\alpha$-LA and $\beta$-LG had been hydrolyzed into small peptides; BSA remained because it is relatively resistant to trypsin hydrolysis (Pacheco et al., 2002). This is a limitation for the enzymes we used; future work could 


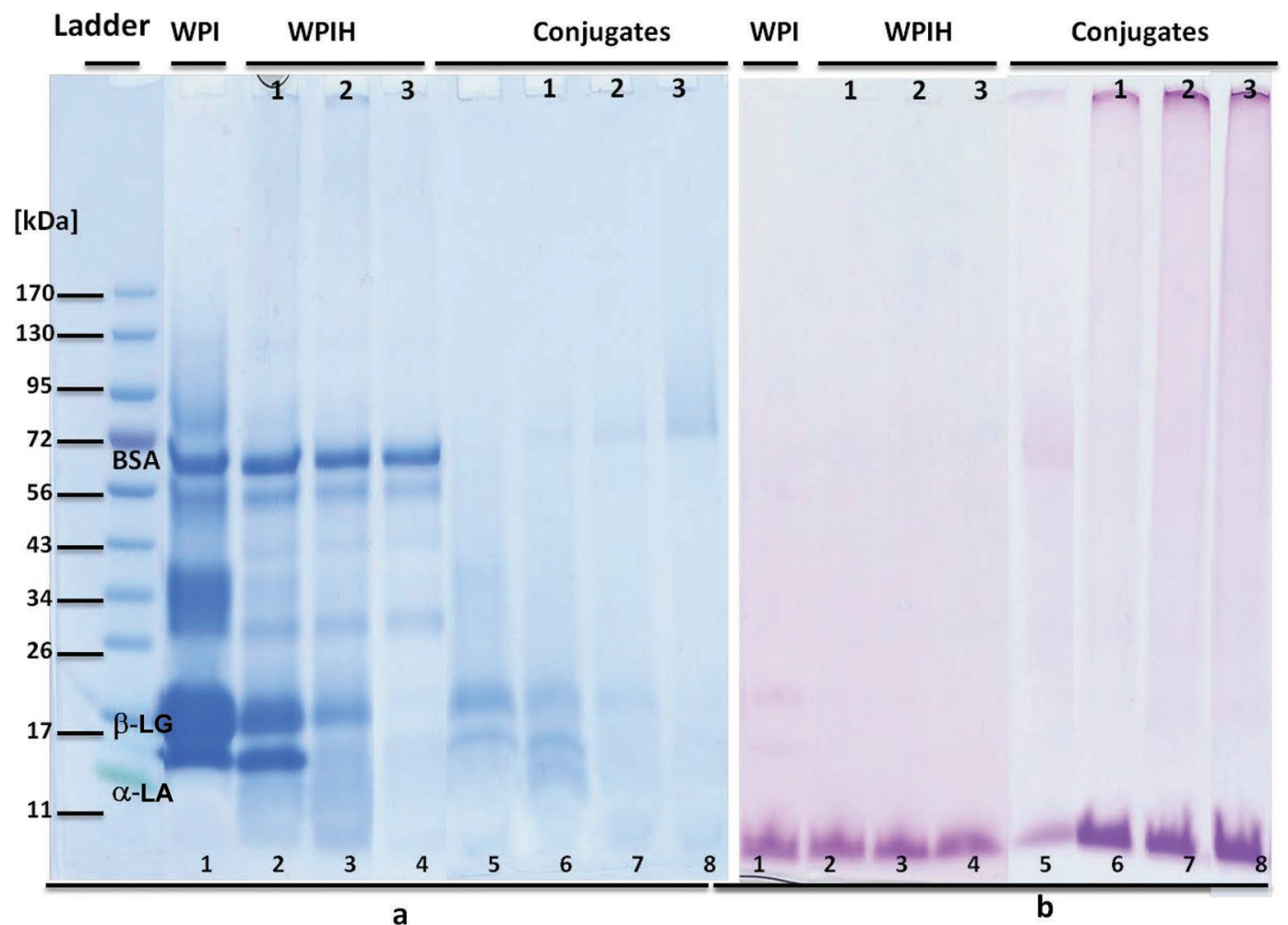

Figure 3. The SDS-PAGE gels of whey protein isolates (WPI), whey protein isolate hydrolysates (WPIH), and corresponding glycates in Laemmli buffer and 5\% 2-mercaptoethanol. (a) Protein-specific Coomassie Brilliant Blue staining; (b) glycoprotein-specific periodic acid staining. Lane 1, WPI without treatment; lane 2, WPIH-1; lane 3, WPIH-2; lane 4, WPIH-3; lane 5, whey protein isolate glycates with dextran (WPI-DX); lane 6, WPIH-1-DX; lane 7, WPIH-2-DX; lane 8, WPIH-3-DX.

include additional enzymes that digest BSA, as well as any other intact protein bands, to reduce the risk of patients reacting to these proteins. Under nonreducing conditions, BSA and $\alpha$-LA can be aggregated after heat treatment (De Wit, 1990); these proteins were likely mostly removed after centrifugation (Xu et al., 2018). In comparing the initial WPI and WPIH materials (lanes 1-4; Figure 3b) and solutions after heating for 24 h (lanes 5-8; Figure 3b), faint magenta bands appeared after heating for the WPIH samples; they were located mostly near the bottom of the gel because the average $M_{W}$ was very small after trypsin hydrolysis (pure DX does not migrate through the gel electric field because it is uncharged). Some DX appeared at the top of the gels (unresolved) for the WPIH-DX samples (lanes 6-8; Figure $3 \mathrm{~b}$ ), indicating that not all DX was used for glycation.

Increasing the $\mathrm{DH}$ value resulted in a significant increase in accessible $\mathrm{NH}_{2}$ groups (Figure 4). Trypsin cleaves at the C-terminal end of Arg and Lys residues, but chymotrypsin requires an aromatic or bulky nonpolar side chain (Phe, Tyr, Trp, Leu, Met) on the carboxyl side of the scissile bond. Twenty-four major peptide fragments were previously identified in a tryp-

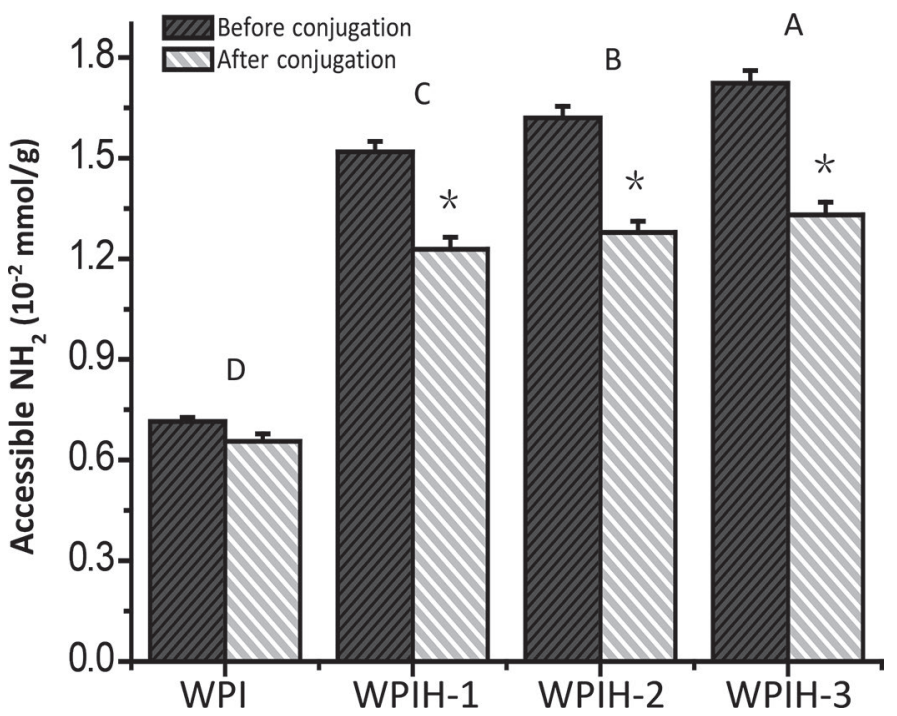

Figure 4. Accessible $\mathrm{NH}_{2}$ groups in native whey protein isolates (WPI), whey protein isolate hydrolysates (WPIH), and corresponding glycates determined using the $o$-phthaldialdehyde method. Data are presented as mean \pm standard deviation. Statistical analysis was performed using 2 -way ANOVA $(P<0.05)$. Different uppercase letters $(\mathrm{A}-\mathrm{D})$ represent significant differences among samples $(P<0.05)$. *Significant difference within samples between WPIH (before conjugation) and corresponding glycates (after conjugation; $P<0.05$ ). 
tic hydrolysate of $\beta$-LG, with $M_{W}$ ranging from 247 to 4,298 Da (Maynard et al., 1998).

The DG between WPIH and DX was related to the value of the $\mathrm{DH}$. We found an increase of $\mathrm{DG}$ as the $\mathrm{DH}$ value increased (Figure 4). After glycation, the amount of accessible $\mathrm{NH}_{2}$ groups was reduced to 91.8, 80.9, 78.9 , and $77.2 \%$ for WPI-DX, WPIH-1-DX, WPIH-2DX, and WPIH-3-DX, respectively, compared with unglycated WPI/WPIH. The calculated DG values were 8.2, 19.2, 21.1, and $22.8 \%$ for WPI-DX, WPIH-1-DX, WPIH-2-DX, and WPIH-3-DX, respectively. Incubation of WPI/WPIH under the same conditions did not lead to any detectable loss of $\mathrm{NH}_{2}$ groups (data not shown). The potential glycation sites on WPIH for the Maillard reaction were mainly $\mathrm{NH}_{2}$ groups in the $\mathrm{N}$ terminal and on Lys. Therefore, tryptic hydrolysis facilitated the Maillard reaction between WPIH and DX by cleaving WPI into small peptides and exposing more free $\mathrm{NH}_{2}$ groups. On average, there are 17 accessible $\mathrm{NH}_{2}$ groups in WPI; therefore, the calculated binding ratios between WPI/WPIH and DX were 1.5, 7, 8, and 9 for WPI-DX, WPIH-1-DX, WPIH-2-DX, and WPIH3-DX, respectively (based on data from Figure 4).

The sensory assessment of bitterness in WPIH and WPIH-DX solutions are shown in Figure 5. Very low levels of bitterness were detected in WPI, but hydrolysis resulted in a significant increase in bitterness, in agreement with previous studies (Leksrisompong et al., 2010). The WPIH with higher levels of DH resulted in higher bitterness scores. Bitterness is caused by extensive exposure of hydrophobic groups in hydrolyzed peptides (Svenning et al., 2000). Glycation of WPIH samples resulted in a significant reduction in bitterness scores. Bitter taste perception is mediated by bitter

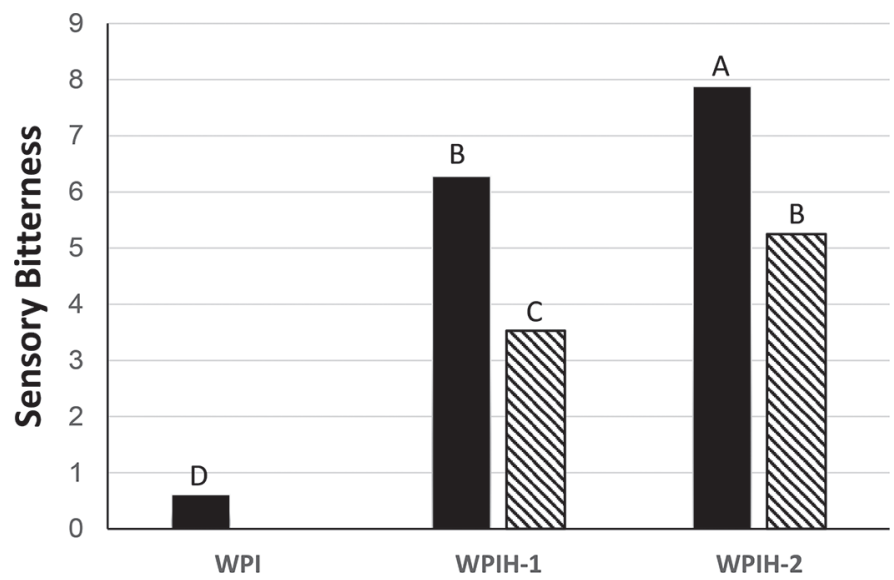

Figure 5. Sensory bitterness scores for whey protein isolates (WPI) and whey protein isolate hydrolysates 1 (WPIH-1) and WPIH-2 (solid bars), as well as corresponding whey protein isolate glycates with dextran (WPIH-DX; hatched bars). Different uppercase letters (A-D) represent significant differences among samples $(P<0.05)$. taste receptors, which are expressed in the oral cavity (Jaggupilli et al., 2016). Presumably, attachment of DX molecules to WPIH peptides provided steric hindrance and reduced the ability of bitter peptides to be detected by these taste receptors. Liu et al. (2012) reported that extensive hydrolysis of soy protein and subsequent glycation with xylose altered its sensory flavor attributes, including reduced bitterness.

\section{IgE Binding Capacity of WPIH-DX Glycates}

To evaluate the allergenicity of the glycates, we determined IgE binding capacity by incubating glycates with sera from blood samples obtained from patients with a CMPA, followed by IgE-specific ImmunoCAP testing. The sera from 8 CMPA patients were combined equally to avoid individual differences. We observed no statistical difference for the negative control (sodium phosphate buffer solution), wheat protein, or DX, indicating that no nonspecific IgE binding had occurred during pre-incubation (data not shown). The IgE binding capacity of WPIH and glycates were expressed as a percentage of the $\operatorname{IgE}$ binding capacity of WPI (Figure 6). Compared with WPI, hydrolysis of WPI decreased the $\operatorname{IgE}$ binding capacity by 58,69 , and $73 \%$ for the WPIH-1, WPIH-2, and WPIH-3 samples, respectively.

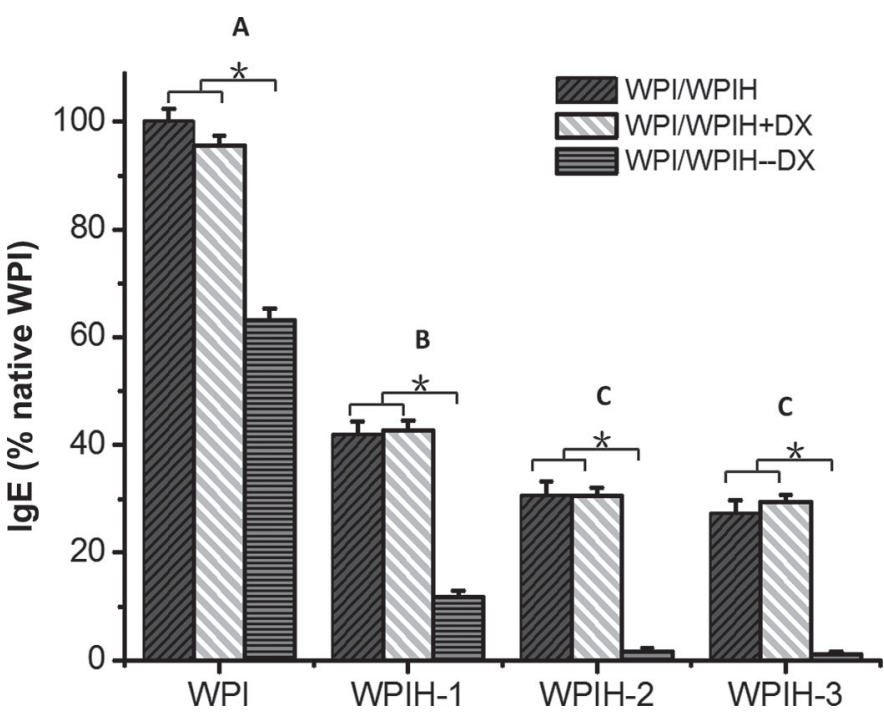

Figure 6. The $\operatorname{IgE}$ binding capacity of whey protein isolates (WPI), whey protein isolate hydrolysates (WPIH), whey protein isolate mixed with dextran (WPI+DX mixture), whey protein isolate hydrolysates mixed with DX (WPIH+DX mixture), and glycates of WPI-DX and WPIH-DX determined by ImmunoCAP test (Phadia, Uppsala, Sweden). Results are expressed as a percentage of IgE bound to the native WPI. Results are the means and standard deviations of triplicate measurements. Statistical analysis was performed using 2 -way ANOVA $(P<0.05)$. Different uppercase letters $(\mathrm{A}-\mathrm{C})$ represent significant differences among samples $(P<0.05)$. * Significant difference from glycates within samples after treatment $(P<0.05)$. 
This reduction in IgE binding with increasing $\mathrm{DH}$ was consistent with trends from previous studies that demonstrated a reduction in immunogenicity in hydrolysates (Leary, 1992; Szajewska and Horvath, 2010). Hydrolysis is a well-known method for reducing the allergenicity of whey proteins, which is influenced by the $\mathrm{DH}$ value, as well as specific types of enzymes used for hydrolysis.

Small peptides $(<1,400 \mathrm{Da})$ are considered to have limited IgE binding capacity (Van Hoeyveld et al., 1998), with few allergenic epitopes remaining. The $M_{W}$ of WPIH decreased with increasing DH: we found $M_{W}$ average values of $11.2,9.5$, and $7.6 \mathrm{kDa}$ for the WPIH-1, WPIH-2 and WPIH-3 samples, respectively. In agreement with that trend, the lowest IgE binding capacity was observed in WPIH-3, which had the highest DH $(27.1 \%)$ and lowest average $M_{W}(7.6 \mathrm{kDa})$; intact BSA probably helped increase the overall average $M_{W}$ of the samples. The reduction in $\operatorname{IgE}$ binding capacity was likely due to cleavage of potential allergenic epitopes, mainly linear epitopes, during hydrolysis (Wroblewska et al., 2004; Hays and Wood, 2005).

However, hydrolysis alone was not enough to completely eliminate most of the $\operatorname{IgE}$ binding capacity (Figure 6), because allergenic epitopes remained on the residual peptides in the WPIH samples. Extensive protein hydrolysis can result in the development of bitterness, which increased with $\mathrm{DH}$ in our samples (Figure 5). Therefore, we studied the glycation of WPIH with DX as a way of reducing the IgE binding capacity.

Compared with WPI, the glycation of WPIH with DX resulted in IgE binding capacity values of 63,12 , 1.6 , and $1.0 \%$ for the WPI-DX, WPIH-1-DX, WPIH2-DX, and WPIH-3-DX samples, respectively (Figure 6). We found no statistical difference between the WPI and WPI+DX mixtures, or between the WPIH and WPIH+DX mixtures $(P>0.05)$, indicating that no nonspecific IgE binding occurred for DX. The WPIHDX glycates had a significantly lower WPI-specific IgE binding capacity than their corresponding unglycated WPIH samples (Figure 6), demonstrating that glycation via the Maillard reaction significantly reduced the allergenicity of WPIH.

Glycation of WPIH with DX could cause a modification in possible linear epitopes on peptides, providing a "shielding effect" on these peptides and creating steric hindrance around the peptide surface, which could limit the access to IgE binding (Hattori et al., 2004; TaheriKafrani et al., 2009; Corzo-Martínez et al., 2010; Xu et al., 2018). The largest reduction in IgE binding was achieved in WPIH-3, which had the highest DG, the highest $\mathrm{DH}$, and the lowest average $M_{W}$. In this way, we demonstrated that a combined hydrolysis-glycation process successfully produced whey protein ingredients with dramatically reduced allergenicity. Glycation likely reduces available lysine, and an in vitro digestion model showed that whey protein glycates are digested, but at a lower rate than unglycated protein (Böttger et al., 2013). Further work could use in vivo methods to further assess the allergenicity of these novel glycates, because not all allergic responses are IgE-mediated. Additional in vivo tests would be needed to understand whether people with a CMPA better tolerate (i.e., experience less symptoms from) these glycates than existing milk protein products.

\section{CONCLUSIONS}

Enzymatic hydrolysis combined with glycation significantly reduced the IgE binding capacity of WPI. In this study, WPI was hydrolyzed by immobilized trypsin and chymotrypsin into peptides followed by glycation of WPIH with DX. Protein hydrolysis created more accessible groups for glycation, enhancing the DG. Glycation of the WPIH samples reduced their bitterness, presumably by interfering with the sensory perception of bitterness. The IgE binding results from ImmunoCAP indicated that WPIH reduced allergenicity compared with WPI, and that WPIH-DX glycation lowered IgE binding capacity even further. This combined processing method could be an interesting approach to producing formula for people with a CMPA, and this formula may have better flavor and solubility than extensively hydrolyzed whey proteins.

\section{ACKNOWLEDGMENTS}

This project was funded by the National Institute of Food and Agriculture of the United States Department of Agriculture (Washington, DC). We express our sincere thanks to Christopher Tisler, Yanjie Lu, Bingqing Cai, and Shane Crowley from the University of Wisconsin-Madison for their valuable input into this project.

\section{REFERENCES}

Allelein, S., A. Arunkumar, and M. R. Etzel. 2012. Method for chromatographic analysis of whey protein-dextran glycation products. J. Chromatogr. A 1270:330-333. https://doi.org/10.1016/j.chroma 2012.10.070.

Ballmer-Weber, B. K. 2011. Allergic reactions to food proteins. Int. J. Vitam. Nutr. Res. 81:173-180. https://doi.org/10.1024/0300 $-9831 / a 000055$.

Böttger, F. H., M. R. Etzel, and J. A. Lucey. 2013. In vitro infant digestion of whey protein-dextran glycates. Food Dig. 4:76-84. https: //doi.org/10.1007/s13228-013-0032-6.

Calabria, C. W., J. Dietrich, and L. Hagan. 2009. Comparison of serum-specific IgE (ImmunoCAP) and skin-prick test results for 53 
inhalant allergens in patients with chronic rhinitis. Allergy Asthma Proc. 30:386-396. https://doi.org/10.2500/aap.2009.30.3258.

Church, F. C., H. E. Swaisgood, D. H. Porter, and G. L. Catignani. 1983. Spectrophotometric assay using o-phthaldialdehyde for determination of proteolysis in milk and isolated milk proteins. J. Dairy Sci. 66:1219-1227. https://doi.org/10.3168/jds.S0022 -0302(83)81926-2.

Corzo-Martínez, M., A. C. Soria, J. Belloque, M. Villamiel, and F. J. Moreno. 2010. Effect of glycation on the gastrointestinal digestibility and immunoreactivity of bovine $\beta$-lactoglobulin. Int. Dairy J. 20:742-752. https://doi.org/10.1016/j.idairyj.2010.04.002.

Custodio, M. F., A. J. Goulart, D. P. Marques, R. C. Giordano, R. L. C. Giordano, and R. Monti. 2005. Hydrolysis of cheese whey proteins with trypsin, chymotrypsin and carboxypeptidase. A. Alim. Nutr. Araraquara 16:105-109. (In Spanish).

de Oliveira, F. C., J. S. Coimbra, E. B. de Oliveira, A. D. Zuñiga, and E. E. Rojas. 2016. Food protein-polysaccharide conjugates obtained via the Maillard reaction: A review. Crit. Rev. Food Sci. Nutr. 56:1108-1125. https://doi.org/10.1080/10408398.2012 .755669 .

De Wit, J. N. 1990. Thermal stability and functionality of whey proteins. J. Dairy Sci. 73:3602-3612. https://doi.org/10.3168/jds .S0022-0302(90)79063-7.

Dupont, C., and D. De Boissieu. 2003. Formula feeding during cow's milk allergy. Minerva Pediatr. 55:209-216.

Dus, C., L. Stapleton, A. Trial, A. R. Krogmann, and G. V. Civille. 2018. Spectrum method. Pages 319-353 in Descriptive Analysis in Sensory Evaluation. S. E. Kemp, J. Hort, and T. Hollowood, ed. John Wiley \& Sons, Hoboken, NJ.

Giampietro, P. G., N.-I. M. Kjellman, G. Oldaeus, W. Wouters-Wesseling, and L. Businco. 2001. Hypoallergenicity of an extensively hydrolyzed whey formula. Pediatr. Allergy Immunol. 12:83-86. https://doi.org/10.1034/j.1399-3038.2001.012002083.x.

Guisán, J. M., A. Bastida, C. Cuesta, R. Fernandez-Lufuente, and C. M. Rosell. 1991. Immobilization-stabilization of alpha-chymotrypsin by covalent attachment to aldehyde-agarose gels. Biotechnol. Bioeng. 38:1144-1152. https://doi.org/10.1002/bit.260381005.

Hattori, M., S. Miyakawa, Y. Ohama, H. Kawamura, T. Yoshida, K. To-o, T. Kuriki, and K. Takahashi. 2004. Reduced immunogenicity of beta-lactoglobulin by conjugation with acidic oligosaccharides. J. Agric. Food Chem. 52:4546-4553. https://doi.org/10.1021/ jf0353887.

Hays, T., and R. A. Wood. 2005. A systematic review of the role of hydrolyzed infant formulas in allergy prevention. Arch. Pediatr. Adolesc. Med. 159:810-816. https://doi.org/10.1001/archpedi.159 .9.810.

Høst, A. 2002. Frequency of cow's milk allergy in childhood. Ann. Allergy Asthma Immunol. 89:33-37. https://doi.org/10.1016/S1081 $-1206(10) 62120-5$.

Jaggupilli, A., R. Howard, J. D. Upadhyaya, R. P. Bhullar, and P. Chelikani. 2016. Bitter taste receptors: Novel insights into the biochemistry and pharmacology. Int. J. Biochem. Cell Biol. 77:184196. https://doi.org/10.1016/j.biocel.2016.03.005.

Jiménez-Castaño, L., M. Villamiel, and R. López-Fandiño. 2007. Glycosylation of individual whey proteins by Maillard reaction using dextran of different molecular mass. Food Hydrocoll. 21:433-443. https://doi.org/10.1016/j.foodhyd.2006.05.006.

Johansson, S. G. O. 2004. ImmunoCAP Specific IgE test: An objective tool for research and routine allergy diagnosis. Expert Rev. Mol. Diagn. 4:273-279. https://doi.org/10.1586/14737159.4.3.273.

Jung, S. H., S. J. Choi, H. J. Kim, and T. M. Moon. 2006. Molecular characteristics of bovine serum albumin-dextran conjugates. Biosci. Biotechnol. Biochem. 70:2064-2070. https://doi.org/10.1271/ bbb. 60026 .

Kobayashi, K., A. Hirano, A. Ohta, T. Yoshida, K. Takahashi, and M. Hattori. 2001. Reduced immunogenicity of $\beta$-lactoglobulin by conjugation with carboxymethyl dextran differing in molecular weight. J. Agric. Food Chem. 49:823-831. https://doi.org/10 $.1021 /$ jf000926q.
Laemmli, U. K. 1970. Cleavage of structural proteins during the assembly of the head of bacteriophage T4. Nature 227:680-685. https://doi.org/10.1038/227680a0.

Leary, H. L. Jr. 1992. Nonclinical testing of formulas containing hydrolyzed milk protein. J. Pediatr. 121:S42-S46. https://doi.org/10 .1016/S0022-3476(05)81405-2.

Leksrisompong, P. P., R. E. Miracle, and M. A. Drake. 2010. Charcaterization of flavor of whey protein hydrolysates. J. Agric. Food Chem. 58:6318-6327. https://doi.org/10.1021/jf100009u.

Liu, P., M. Huang, S. Song, K. Hayat, X. Zhang, S. Xia, and C. Jia. 2012. Sensory characteristics and antioxidant activities of Maillard reaction products from soy protein hydrolysates with different molecular weight distribution. Food Bioprocess Technol. 5:1775-1789. https://doi.org/10.1007/s11947-010-0440-3.

Lucey, J. A., M. Srinivasan, H. Singh, and P. A. Munro. 2000. Characterization of commercial and experimental sodium caseinates by multiangle laser light scattering and size-exclusion chromatography. J. Agric. Food Chem. 48:1610-1616. https://doi.org/10.1021/ jf990769z.

Maynard, F., A. Weingand, J. Hau, and R. Jost. 1998. Effect of high-pressure treatment on the tryptic hydrolysis of bovine 3-lactoglobulin AB. Int. Dairy J. 8:125-133. https://doi.org/10 .1016/S0958-6946(98)00030-2

Mulcahy, E. M., C. W. Park, M. Drake, D. M. Mulvihill, and J. A. O'Mahony. 2016. Improvement of the functional properties of whey protein hydrolysate by conjugation with maltodextrin. Int. Dairy J. 60:47-54. https://doi.org/10.1016/j.idairyj.2016.02.049.

Ng, D. H. C., J. Klassen, N. D. Embleton, and W. McGuire. 2017. Protein hydrolysate versus standard formula for preterm infants. Cochrane Database Syst. Rev. 10:CD012412. https://doi.org/10 .1002/14651858.CD012412.pub2.

Nielsen, P. M., D. Petersen, and C. Dambmann. 2001. Improved method for determining food protein degree of hydrolysis. J. Food Sci. 66:642-646. https://doi.org/10.1111/j.1365-2621.2001.tb04614.x.

Nnanna, I. A., and C. Wu. 2007. Dairy protein hydrolysates. Pages 537-556 in Handbook of Food Products Manufacturing. Y. H. Hui, ed. John Wiley \& Sons, Hoboken, NJ.

O'Mahony, J. A., K. P. Drapala, E. M. Mulcahy, and D. M. Mulvihill. 2017. Controlled glycation of milk proteins and peptides: Functional properties. Int. Dairy J. 67:16-34. https://doi.org/10.1016/ j.idairyj.2016.09.012.

Pacheco, M. T. B., J. Amaya-Farfan, and V. C. Sgarbieri. 2002. Partial characterization of a whey protein concentrate and its enzyme hydrolysates. J. Food Biochem. 26:327-338. https://doi.org/10.1111/ j.1745-4514.2002.tb00757.x.

Pan, D. D., Z. Wu, J. Liu, X. Y. Cao, and X. Q. Zeng. 2013. Immunomodulatory and hypoallergenic properties of milk protein hydrolysis in ICR mice. J. Dairy Sci. 96:4958-4964. https://doi.org/10 $.3168 /$ jds.2013-6758.

Puerta, A., J. C. Diez-Masa, and M. de Frutos. 2006. Immunochromatographic determination of $\beta$-lactoglobulin and its antigenic peptides in hypoallergenic formulas. Int. Dairy J. 16:406-414. https://doi.org/10.1016/j.idairyj.2005.05.006.

Reche, M., C. Pascual, A. Fiandor, I. Polanco, M. Rivero-Urgell, R. Chifre, S. Johnston, and M. Martín-Esteban. 2010. The effect of a partially hydrolysed formula based on rice protein in the treatment of infants with cow's milk protein allergy. Pediatr. Allergy Immunol. 21(4 Pt 1):577-585. https://doi.org/10.1111/j.1399-3038.2010 $.00991 . x$

Sampson, H. A. 2001. Utility of food-specific IgE concentrations in predicting symptomatic food allergy. J. Allergy Clin. Immunol. 107:891-896. https://doi.org/10.1067/mai.2001.114708.

Shainoff, J. R. 1980. Zonal immobilization of proteins. Biochem. Biophys. Res. Commun. 95:690-695. https://doi.org/10.1016/0006 $-291 X(80) 90840-2$.

Svenning, C., J. Brynhildsvold, T. Molland, T. Langsrud, and G. E. Vegarud. 2000. Antigenic response of whey proteins and genetic variants of $\beta$-lactoglobulin - The effect of proteolysis and processing. Int. Dairy J. 10:699-711. https://doi.org/10.1016/S0958 -6946(00)00101-1. 
Szajewska, H., and A. Horvath. 2010. Meta-analysis of the evidence for a partially hydrolyzed $100 \%$ whey formula for the prevention of allergic diseases. Curr. Med. Res. Opin. 26:423-437. https://doi .org/10.1185/03007990903510317.

Taheri-Kafrani, A., J. C. Gaudin, H. Rabesona, C. Nioi, D. Agarwal, M. Drouet, J. M. Chobert, A. K. Bordbar, and T. Haertle. 2009 Effects of heating and glycation of beta-lactoglobulin on its recognition by $\operatorname{IgE}$ of sera from cow milk allergy patients. J. Agric. Food Chem. 57:4974-4982. https://doi.org/10.1021/jf804038t.

Van Hoeyveld, E. M., M. Escalona-Monge, L. F. de Swert, and E. A. Stevens. 1998. Allergenic and antigenic activity of peptide fragments in a whey hydrolysate formula. Clin. Exp. Allergy 28:11311137. https://doi.org/10.1046/j.1365-2222.1998.00381.x.

Wal, J.-M. 1998. Cow's milk allergens. Allergy 53:1013-1022. https:// doi.org/10.1111/j.1398-9995.1998.tb03811.x.

Wal, J.-M. 2002. Cow's milk proteins/allergens. Ann. Allergy Asthma Immunol. 89:3-10. https://doi.org/10.1016/S1081-1206(10)62115 -1 .

Wang, T., and J. A. Lucey. 2003. Use of multi-angle laser light scattering and size-exclusion chromatography to characterize the molecular weight and types of aggregates present in commercial whey protein products. J. Dairy Sci. 86:3090-3101. https://doi.org/10 $.3168 /$ jds.S0022-0302(03)73909-5.
Wroblewska, B., M. Karamac, R. Amarowicz, A. Szymkiewicz, A. Troszynska, and E. Kubicka. 2004. Immunoreactive properties of peptide fractions of cow whey milk proteins after enzymatic hydrolysis. Int. J. Food Sci. Technol. 39:839-850. https://doi.org/10 .1111/j.1365-2621.2004.00857.x.

Xu, L., Y. S. Gong, J. E. Gern, S. Ikeda, and J. A. Lucey. 2018. Glycation of whey protein with dextrans of different molar mass: Effect on immunoglobulin E-binding capacity with blood sera obtained from patients with cow milk protein allergy. J. Dairy Sci. 101:6823-6834. https://doi.org/10.3168/jds.2017-14338.

Zhu, D., S. Damodaran, and J. A. Lucey. 2008. Formation of whey protein isolate (WPI)-dextran conjugates in aqueous solutions. J. Agric. Food Chem. 56:7113-7118. https://doi.org/10.1021/ jf800909w.

\section{ORCIDS}

Lei Xu • https://orcid.org/0000-0001-8280-3162

Yuansheng Gong ๑ https://orcid.org/0000-0002-3175-4281

James E. Gern (ㅇ https://orcid.org/0000-0002-6667-4708

John A. Lucey (ํ) https://orcid.org/0000-0002-8838-5130 